\title{
Evaluation of antidiarrheal activity of ethanolic extract of Holarrhena antidysenterica seeds in rats
}

\author{
Dushyant Kumar Sharma, Vinod Kumar Gupta, Surendra Kumar, Vivek Joshi, Ravi Shankar Kumar Mandal, \\ A. G. Bhanu Prakash and Mamta Singh

\begin{abstract}
Division of Medicine, Indian Veterinary Research Institute, Izatnagar, Bareilly, Uttar Pradesh - 243122 , India. Corresponding author: Dushyant Kumar Sharma, e-mail: dr.dushsharma@gmail.com, VKG: vinodgupta1288@gmail.com, SK: mailmesbansal@gmail.com, VJ: joshignet@gmail.com, RSKM: dr.ravi0911@gmail.com, AGBP: vetbhanu@gmail.com, MS: mamta2947@gmail.com

Received: 01-06-2015, Revised: 25-10-2015, Accepted: 31-10-2015, Published online: 11-12-2015
\end{abstract}

doi: 10.14202/vetworld.2015.1392-1395 How to cite this article: Sharma DK, Gupta VK, Kumar S, Joshi V, Mandal RSK, Prakash AGB, Singh M (2015) Evaluation of antidiarrheal activity of ethanolic extract of Holarrhena antidysenterica seeds in rats, Veterinary World 8(12): 1392-1395.

\begin{abstract}
Aim: The present study was conducted to evaluate the antidiarrheal effect of ethanolic extract of Holarrhena antidysenterica (Family - Apocynaceae) seeds against induced diarrhea in Wistar albino rats.

Materials and Methods: The extract was evaluated for castor oil and Escherichia coli induced diarrhea. Extract was given at $100,200,400 \mathrm{mg} / \mathrm{kg}$ body wt. orally in both protocols. Standard antidiarrheal Loperamide was used at $5 \mathrm{mg} / \mathrm{kg}$ body wt. orally in castor oil induced protocol, while standard antibiotic Gentamicin at $8 \mathrm{mg} / \mathrm{kg}$ body wt. intraperitoneally was used in $E$. coli induced diarrhea. In castor oil induced protocol, the percentage inhibition of defecation was calculated for each group, whereas in E. coli induced protocol, change in fecal consistency, and body weight was recorded for each individual rat for 3 days.

Results: The severity of castor oil induced diarrhea was reduced significantly $(\mathrm{p}<0.05)$ with $H$. antidysenterica seeds extract at 200 and $400 \mathrm{mg} / \mathrm{kg}$ body wt. which showed equivalent effectiveness like that of Loperamide treated groups. Similarly in $E$. coli induced diarrhea protocol, the mean change in body weight was significantly $(\mathrm{p}<0.05)$ higher in positive control, whereas no significant variation was observed in negative control, Gentamicin treated and H. antidysenterica treated group at $200 \mathrm{mg} / \mathrm{kg}$ and $400 \mathrm{mg} / \mathrm{kg}$ body wt., respectively.
\end{abstract}

Conclusion: The study concluded that ethanolic extract of $H$. antidysenterica seeds effectively controlled diarrhea and decreased the severity of clinical signs of castor oil and $E$. coli induced diarrhea in Wistar rats.

Keywords: antidiarrheal, Escherichia coli, Holarrhena antidysenterica.

\section{Introduction}

Diarrhea is the symptom of the gastrointestinal disorder, characterized by increase in stool frequency and alteration in consistency [1]. Diarrhea and the associated fecal urgency and incontinence result into imbalance between the absorptive and secretory mechanisms in the intestinal tract accompanied by hypermotility resulting in the excess loss of body fluids and electrolytes in feces [2]. Diarrhea is considered as the most imperative cause of death in neonatal farm animals worldwide. To nullify the problem of diarrhea in developing countries, the World Health Organization has constituted a diarrheal disease control program, which includes studies of traditional medicinal practices, together with health education and prevention strategies [3]. India is very rich harbor with reference to the diversity of higher plant species and also one of the leading countries in Asia with respect to a wealth of traditional knowledge system related to the use of plant species. Plants are very important sources of antidiarrheal drugs [4].

Copyright: The authors. This article is an open access article licensed under the terms of the Creative Commons Attributin License (http:// creative commons.org/licenses/by/2.0) which permits unrestricted use, distribution and reproduction in any medium, provided the work is properly cited.
Holarrhena antidysenterica (FamilyApocynaceae, Common Name: Kutaza, Bitter Oleander, Kurchi) is a large tree, 9-10 meter long usually found in mountain areas. Seeds are linear or oblong concave with a long coma shape, light brown in color and show epigeal germination. Unani and Ayurvedic system of medicine utilizes this splendid herbal drug against many infectious diseases caused by helminthes, Staphylococcus aureus, Entamoeba histolytica, and Escherichia coli infections [5]. The bark and seeds of Holarrhena antidysenterica have been used for amoebic dysentery, diarrhea, asthma, bronchopneumonia, piles, eczema, fever, malaria, and diabetes mellitus [6,7]. $H$. antidysenterica produces gastrointestinal tract stimulation by activation of histamine receptors and relaxes the gastrointestinal tract by $\mathrm{Ca}^{++}$channel blockade, which provided the basic ground for its usefulness in gut motility problems such as constipation, colic and diarrhea [8]. In past few years, due to the development of antibiotic resistance against infectious agents, plant kingdom has been extensively explored for its potential antimicrobial activity. The aim of present study was to evaluate the antidiarrheal activity of $H$. antidysenterica seeds against infectious and non-infectious diarrhea in Wistar rats. 


\section{Materials and Methods}

\section{Ethical approval}

The present study was given ethical clearance by Institutional Animal Ethical Committee. Animals were handled as per the guidelines of Committee for the Purpose of Control and Supervision of Experiments on Animals.

\section{Extract preparation}

$H$. antidysenterica seeds were procured from local market. The seeds were authenticated by Dr. Dinesh K Saxena, Professor Emeritus (UGC), Department of Botany, Bareilly College, Bareilly. The voucher specimen (assigned no. 201401022879 0332a) was deposited in college for further reference. The seeds were washed with distilled water, dried in shade, separated and made to dry powder. It was then passed through the 40 mesh sieve. Weighed amount of plant material was subjected to ethanolic columnar extraction in Soxhlet assembly as per standard protocol [9]. The extraction process was carried up to $12-15$ cycles. The extract was dried at a temperature of $41^{\circ} \mathrm{C}$ and yielded brown colored powder weighing $8.3 \%$, which was stored at $2-4^{\circ} \mathrm{C}$ for phytochemical analysis [10] and further use for evaluation of the antidiarrheal activity.

\section{Experimental animals, grouping and procedure}

A total of 60 Wistar Albino rats (Indent voucher no. 6675) weighing 150-200 g were obtained from the Laboratory Animal Research Section (LAR) of IVRI, Izatnagar, Bareilly. The rats were kept in well ventilated experimental shed of medicine division under 12:12 light and dark hours in propylene cages. The animals were given weighed amount of standard feed supplied by feed section of IVRI and water ad libitum. Diarrhea was induced following two protocols with castor oil and E. coli.

\section{Castor oil induced diarrhea}

The rats were divided into 6 groups of 5 rats in each group and acclimatized for 7 days in the experimental shed. Rats were fasted for $18 \mathrm{~h}$ before conducting the study. Group A-I received normal saline at $20 \mathrm{ml} / \mathrm{kg}$ body wt. served as negative control, Group A-II as positive control received normal saline at $20 \mathrm{ml} / \mathrm{kg}$ body wt., G A-III as standard treatment received Loperamide at $5 \mathrm{mg} / \mathrm{kg}$ body wt., and Group A-IV, Group A-V and Group A-VI were kept at $100 \mathrm{mg} / \mathrm{kg}, 200 \mathrm{mg} / \mathrm{kg}$ and $400 \mathrm{mg} / \mathrm{kg}$ body wt. $H$. antidysenterica seeds extract dosages for 3 days, respectively. All dosages were given orally. After $1 \mathrm{~h}$ of treatment, diarrhea was induced by oral gavage of castor oil (VASCO DRUG LABORATORIES, Agra) at $1 \mathrm{ml} /$ rat in all groups except negative control [11]. All rats were transferred to propylene cages with absorbent paper and observed for watery wet or unformed stools for the next $4 \mathrm{~h}$. A total number of wet or unformed droppings were counted and mean number of droppings/rat was calculated. The percentage inhibition of defecation was calculated for each group as per the following formula.
Percentage inhibition of defecation/drooping = $([\mathrm{A}-\mathrm{B}] / \mathrm{A}) \times 100$

where $\mathrm{A}=$ Mean number of defecations caused by castor oil.

$\mathrm{B}=$ Mean number of defecation caused by drug or extract.

\section{E. coli induced diarrhea}

The rats were divided into 6 groups of 5 rats in each group and acclimatized for 7 days in the experimental shed. Rats were fasted for $18 \mathrm{~h}$ before conducting the study. Group B-I and Group B-II served as negative control and positive control, respectively, and both received normal saline at $5 \mathrm{ml} / \mathrm{kg}$ body wt. Group B-III as standard treatment received antibiotic Gentamicin at $8 \mathrm{mg} / \mathrm{kg}$ body wt., and Group B-IV, Group B-V and Group B-VI, were kept at $100 \mathrm{mg} / \mathrm{kg}$, $200 \mathrm{mg} / \mathrm{kg}$ and $400 \mathrm{mg} / \mathrm{kg}$ body wt. H. antidysenterica seeds extracts dosages respectively for 3 days. All dosages were given orally. The relevant strain of enterotoxigenic E. coli was obtained from the division of veterinary public health, IVRI, Izatnagar and grown on EMB agar. The E. coli suspension was made in physiological normal saline containing $2 \times 10^{8} \mathrm{CFU} / \mathrm{ml}$, which was calculated by spectrophotometric method. Diarrhea was induced in all groups except negative control by single oral administration of enterotoxigenic E. coli solution incubated at $37^{\circ} \mathrm{C}$ for $1 \mathrm{~h}$ at $5 \mathrm{ml} / \mathrm{kg}$ body wt. The control group without induction of diarrhea received a single oral dose of physiological saline (vehicle) warmed at $37^{\circ} \mathrm{C}$ with an administration volume of $5 \mathrm{ml} / \mathrm{kg}$ [12]. Changes in fecal consistency and body weight were recorded for each individual rat.

\section{Statistical analysis}

Data was subjected to statistical analysis using one-way ANOVA [13] and Tucky HSD SPSS software and $p<0.05$ was considered statistically significant.

\section{Results}

The preliminary phytochemical analysis of $H$. antidysenterica seeds extract revealed the presence of alkaloid, carbohydrates, flavonoids, and phenolic compounds. Diarrhea was clinically apparent in all rats of positive control group after $30 \mathrm{~min}$ of oral administration of castor oil for next $4 \mathrm{~h}$. Significant $(\mathrm{p}<0.05)$ percentage inhibition of defecation was recorded over $4 \mathrm{~h}$ with $H$. antidysenterica seeds extract given at $200 \mathrm{mg} / \mathrm{kg}$ body wt. $(52.27 \pm 3.28)$ and at $400 \mathrm{mg} / \mathrm{kg}$ body wt. (54.18 \pm 1.37$)$ compared to positive control group (Group A-II), whereas similar effect was produced by standard drug, Loperamide given at $5 \mathrm{mg} / \mathrm{kg}$ (Table-1).

In the second protocol of $E$. coli induced, diarrhea was apparent in all groups except negative control (Group B-I) after $3.5 \mathrm{~h}$ of oral administration of E. coli suspension. The fecal consistency was found to be loose, semisolid in all groups on day 0 and 
continued to be loose until day $2^{\text {nd }}$ in all groups but on day $3^{\text {rd }}$ consistency became normal in all groups, except positive control (Group B-II) and $H$. antidysenterica seeds extract at $100 \mathrm{mg} / \mathrm{kg}$ (Group B-IV). No significant difference was observed in body weight of all groups on day 0 . On the $3^{\text {rd }}$ day, a significant difference $(p<0.05)$ was observed between body weights of the different groups. The body weight of $\mathrm{H}$. antidysenterica at $200 \mathrm{mg} / \mathrm{kg}$ body wt. (Group B-V) and $400 \mathrm{mg} / \mathrm{kg}$ body wt. (Group B-VI) treated groups differed significantly $(p<0.05)$ when compared to other groups, except negative control group (Group B-I) and Gentamicin treated group (Group B-III). The mean body weight change was significantly higher in the positive control (Group B-II), whereas negative control group (Group B-I), Gentamicin treated group (Group B-III), H. antidysenterica at $200 \mathrm{mg} / \mathrm{kg}$ body wt. (Group B-V) and $400 \mathrm{mg} / \mathrm{kg}$ body wt. (Group B-VI) did not show significant difference among them. A little drop in the food and water intake was observed in all groups except healthy control group (Table-2).

\section{Discussion}

Diarrhea is defined as increase in the fluidity, volume and frequency of bowel movements, increased secretion and decreased absorption of fluid, and thus loss of water and electrolytes from the body, and it is a hallmark sign of intestinal diseases [14]. The present study revealed the effect of $H$. antidysentrica seeds extract in castor oil induced diarrhea and E. coli induced diarrhea in rats. Castor oil contains an active ingredient ricinoleic acid, which is a hydroxylated unsaturated fatty acid, produced by action of lipases on castor oil in the upper intestine. The ricinoleate in the small gut lumen is poorly absorbed and it alters mucosal permeability, peristalsis and electrolyte transport $\left(\mathrm{Na}^{+}\right.$and $\left.\mathrm{Cl}^{-}\right)$leading to hypersecreation and diarrhea. Ricinoleic acid stimulates epithelial cells to produce nitric oxide and adenylyl cyclase which lead to the production of prostaglandins (E series) induced diarrhea $[15,16]$. Therefore, inhibition of biosynthesis of prostaglandin is considered to inhibit the ricinoleate induced diarrhea [17]. $H$. antidysenterica seeds extract exhibits significant antidiarrheal activity. Plant extracts containing alkaloids, flavonoids, saponins, steroids, and tannins have been reported to possess antidiarrheal activity. Seed extract of $H$. antidysenterica was found positive for alkaloid and flavonoids which may be responsible for its antidiarrheal activity, comparable to standard antidiarrheal drug Loperamide. Enterotoxigenic E. coli produces a secretory-absorptive imbalance with no or little structural or mucosal damage. E. coli produces enterotoxin which increases the cyclic adenosine monophosphate responsible for enormous efflux of water and electrolytes producing watery diarrhea [18]. The present study revealed the significant antidiarrheal activity of $H$. antidysenterica seeds extract in E. coli induced diarrhea comparable to Gentamicin. It was reviewed that $H$. antidysenterica seeds extract encompasses potential antimicrobial activity against Staphylococcus, Salmonella, and E. coli and produces inhibition zone of $7.05 \mathrm{~mm}, 5.50 \mathrm{~mm}$ and $3.95 \mathrm{~mm}$, respectively, on agar plate which is mainly because of the alkaloids conessine present in plant materials [19]. Our study revealed that $H$. antidysenterica

Table-1: Effect of ethanolic extract of seeds of $H$. antidysenterica on castor oil induced diarrhea in rats.

\begin{tabular}{llccc}
\hline $\begin{array}{l}\text { Group } \\
(\mathbf{n}=\mathbf{5})\end{array}$ & Treatment & $\begin{array}{c}\text { Total no. of wet } \\
\text { dropping/cage } \\
\text { in } \mathbf{4} \mathbf{~ h}\end{array}$ & $\begin{array}{c}\text { Average no of } \\
\text { wet dropping/ } \\
\text { animal in } \mathbf{4} \mathbf{~ h}\end{array}$ & $\begin{array}{c}\text { \% Inhibition } \\
\text { of defecation }\end{array}$ \\
\hline Group A-I & Saline at $20 \mathrm{ml} / \mathrm{kg}$ body wt. & $0.00 \pm 0.00^{\mathrm{a}}$ & $0.00 \pm 0.00^{\mathrm{a}}$ & $0.00 \pm 0.00^{\mathrm{a}}$ \\
Group A-II & Saline at $20 \mathrm{ml} / \mathrm{kg}$ body wt. $+1 \mathrm{ml}$ castor oil & $35.00 \pm 0.58^{\mathrm{d}}$ & $7.00 \pm 0.12^{\mathrm{d}}$ & $0.00 \pm 0.00^{\mathrm{a}}$ \\
Group A-III & Loperamide at $5 \mathrm{mg} / \mathrm{kg}$ body wt. $+1 \mathrm{ml}$ castor oil & $15.00 \pm 0.58^{\mathrm{b}}$ & $3.00 \pm 0.12^{\mathrm{b}}$ & $57.17 \pm 0.94^{\mathrm{c}}$ \\
Group A-IV & HAE at $100 \mathrm{mg} / \mathrm{kg}$ body wt. $+1 \mathrm{ml}$ castor oil & $25.00 \pm 0.58^{\mathrm{c}}$ & $5.00 \pm 0.12^{\mathrm{c}}$ & $28.47 \pm 2.83^{\mathrm{b}}$ \\
Group A-V & HAE at $200 \mathrm{mg} / \mathrm{kg}$ body wt. $+1 \mathrm{ml}$ castor oil & $16.67 \pm 0.88^{\mathrm{b}}$ & $3.33 \pm 0.17^{\mathrm{b}}$ & $52.27 \pm 3.28^{\mathrm{c}}$ \\
Group A-VI & HAE at $400 \mathrm{mg} / \mathrm{kg}$ body wt. $+1 \mathrm{ml}$ castor oil & $16.33 \pm 0.33^{\mathrm{b}}$ & $3.26 \pm 0.06^{\mathrm{b}}$ & $54.18 \pm 1.37^{\mathrm{c}}$ \\
\hline
\end{tabular}

Values are expressed as mean \pm SEM $(n=5)$, and bearing different superscript was considered significant $(p<0.05)$ when compared with control groups. $\mathrm{HAE}=$ Ethanolic extract of Holarrhena antidysenterica seed, SEM=Standard error of the mean, $H$. antidysenterica $=$ Holarrhena antidysenterica

Table-2: Effect of ethanolic extract of seeds of $H$. antidysenterica on $E$. coli induced diarrhea in rats.

\begin{tabular}{|c|c|c|c|c|c|c|}
\hline \multirow{2}{*}{$\begin{array}{l}\text { Group } \\
(n=5)\end{array}$} & \multirow[t]{2}{*}{ Treatment } & \multirow{2}{*}{$\begin{array}{l}\text { Feacal } \\
\text { consistency } \\
\text { on } 0 \text { day }\end{array}$} & \multirow{2}{*}{$\begin{array}{l}\text { Feacal } \\
\text { consistency } \\
\text { on } 3 \text { day }\end{array}$} & \multicolumn{2}{|c|}{ Body weight (g) } & \multirow{2}{*}{$\begin{array}{c}\text { Mean body } \\
\text { weight } \\
\text { change }(g)\end{array}$} \\
\hline & & & & 0 day & 3 day & \\
\hline & & Normal & Normal & & & $6.60 \pm 1.69^{\mathrm{ab}}$ \\
\hline roup B-II & Salin & semisolid & semisolid & 187. & 16 & \\
\hline Group B-III & Gentamicin at $8 \mathrm{mg} / \mathrm{kg}$ body wt. & Loose semisolid & Normal & $185.2 \pm 2.71^{\mathrm{a}}$ & $175.80 \pm 1.28^{\mathrm{bc}}$ & $85^{\mathrm{ab}}$ \\
\hline Group B-IV & $\mathrm{HAE}$ at $100 \mathrm{mg} / \mathrm{kg}$ body wt. & Loose semisolid & Loose semisolid & $188.6 \pm 3.14^{a}$ & $169.00 \pm 2.23^{\mathrm{ab}}$ & $14.00 \pm 1.34^{\mathrm{b}}$ \\
\hline Group B-V & HAE at $200 \mathrm{mg} / \mathrm{kg}$ body wt. & Loose semisolid & Normal & $190.2 \pm 2.61^{\mathrm{a}}$ & $189.80 \pm 2.88^{d}$ & $3.80 \pm 0.73^{a}$ \\
\hline Group B-VI & HAE at $400 \mathrm{mg} / \mathrm{kg}$ body wt. & Loose semisolid & Normal & $188.2 \pm 3.32^{\mathrm{a}}$ & $184.60 \pm 2.11^{\mathrm{cd}}$ & $6.00 \pm 2.60^{\mathrm{ab}}$ \\
\hline
\end{tabular}

Values are expressed as mean $\pm \operatorname{SEM}(n=5)$, and bearing different superscript was considered significant $(p<0.05)$ when compared with control groups. HAE=Ethanolic extract of Holarrhena antidysenterica seed, SEM=Standard error of the mean, $H$. antidysenterica $=$ Holarrhena antidysenterica, E. coli=Escherichia coli 
seeds extract may serve as an effective antidiarrheal for gastrointestinal disorders.

\section{Conclusion}

The present study concludes that ethanolic extract of $H$. antidysenterica seeds is effective against noninfectious as well as infectious diarrhea as it possesses antimicrobial and antidiarrheal property. Hence, it can be validated further for its future use.

\section{Authors' Contributions}

The study is the major component of the special problem of first author DKS. VKG provided the guidelines during the work and corrected manuscript. VJ, RSKM, and BPAG assisted in collection of samples and maintenance of experimental rats including weighing and medication. SK and MS assisted in analysis of data. All the authors have read and approved the final manuscript.

\section{Acknowledgments}

The authors are thankful to the Director, ICARIVRI, Izatnagar, Bareilly, Uttar Pradesh, India, for providing the necessary infrastructure required for conducting this research work. The authors express sincere thanks to Head and staff members, division of medicine ICAR-IVRI and Dr. M. R. Verma, Senior Scientist, LES division, ICAR- IVRI for his cooperation during statistical analysis.

\section{Competing Interests}

None of the authors has a financial or personal relationship with other people or organizations that could inappropriately influence or bias the content of the paper.

\section{References}

1. Olatokunboh, A.O., Mofomosara, S.H. and Ekene, O.A. (2010) Evaluation of the antidiarrhoeal effect of Lannea welwitschii Hiern (Anacardiaceae) bark extract. Afr. J. Pharm. Pharmacol., 4(4): 165-169.

2. Ezenwali, M.O., Njoku, O.U. and Okoli, C.O. (2010) Studies on the anti-diarrheal properties of seed extract of Monodora tenuifolia. Int. J. Appl. Res. Nat. Prod., 2(4): 20-26.

3. Damiki, L. and Siva, H. (2011) Ethnomedicinal plants used for diarrhea by tribals of Meghalaya, Northeast India. Pharmacogn. Rev., 5(10): 147-154.

4. Ouyang, H. and Chen, J.D.Z. (2004) Review article: Therapeutic roles of acupuncture in functional gastrointestinal disorders. Aliment. Pharmacol. Ther., 20(8): 831-841.
5. Usmanghani, K., Akhtar, N., Asif, H.M., Akram, M., Ahmed, K., Shaheen, G., Rehman, R., Ahmad, A. and Sumreen, L. (2011) Monograph of Holarrhena antidysenterica (Linn.). wall. Int. J. Phytomed., 2(4): 345-348.

6. Ganapathy, P.S., Ramachandra, Y.L., Sudeep, H.V., Bellamakondi, P.K., Achar, K.S. and Rai, S.P. (2009) Pharmacognostic and phytochemical evaluation of Holarrhena antidysenterica wall. Asian Aust. J. Plant Sci. Biotechnol., 3(1): 47-50.

7. Mana, S., Singhal, S., Sharma, N.K. and Singh, D. (2010) Hypoglycemic effect of Holarrhena antidysenterica seeds on streptozotocin induced diabetic rats. Int. J. Pharm. Tech. Res., 2(2): 1325-1329.

8. Gilani, A.H., Khan, A., Khan. A.U., Bashir, S., Rehman, N.U. and Mandukhail, S.U.R. (2010) Pharmacological basis for the medicinal use of Holarrhena antidysenterica in gut motility disorders. Pharm. Boil., 48(11): 1240-1246.

9. Okeke, M.I., Iroegbu, C.U., Okoli, A.S. and Esimone, C.O. (2001) Evaluation of extracts of the root of Landolphia owerrience for antibacterial activity. J. Ethnopharmacol., 78(2-3): 119-127.

10. Tiwari, P., Kumar, B., Kaur, M., Kaur, G. and Kaur, H. (2011) Phytochemical screening and Extraction: A Review. Int. Pharm. Sci., 1(1): 98-106.

11. Rahman, M.K., Barua, S., Islam, M.F., Islam, M.R., Sayeed, M.A., Parvin, M.S. and Islam, M.E. (2013) Studies on the anti-diarrheal properties of leaf extract of Desmodium puchellum. Asian Pac. J. Trop. Biomed., 3(8): 639-643

12. Bisson, J.F., Hidalgo, S., Rozan, P. and Messaoudi, M. (2009) Preventive effects of different probiotic formulations on travelers' diarrhea model in wistar rats. Digest. Dis. Sci., 55(4): 911-919.

13. Snedecor, G.W. and Cochram, W.G. (1994) Statistical Methods. $8^{\text {th }}$ ed. Iowa State University Press, USA.

14. Awe, E.O., Kolawole, S.O., Wakeel, K.O. and Abiodun, O.O. (2011) Antidiarrheal activity of Pyrenacantha staudtii Engl. (Iccacinaceae) aqueous leaf extract in rodents. $J$. Ethnopharmacol., 137(1): 148-153.

15. Lakshminarayana, M., Shivkumar, H., Rimaben, P. and Bhargava, V.K. (2011) Antidiarrhoeal activity of leaf extract of Moringa Oleifera in experimentally induced diarrhoea in rats. Phytomed., 3: 68-74.

16. Yoshio, K., Kazuko, S., Bunsyo, M., Kazunori, H., Atsushi, I. and Yasuhiro, K. (1999) Relationship between antidiarrhoeal effects of Hange- Shashin-To and its active components. Phytother. Res., 13: 468-473.

17. Sorin, T., Till, F.A., Rolf, M.N., Martin, D. and Stefan, O. (2012) Castor oil induces laxation and uterus contraction via ricinoleic acid activating prostaglandin EP3 receptors. Proc. Natl. Acad. Sci. USA., 109(23): 9179-9184.

18. Kesty, N.C., Mason, K.M., Reedy, M., Miller, S.E. and Kuehn, M.J. (2004) Enterotoxigenic Escherichia coli vesicles target toxin delivery into mammalian cells. EMBO J., 23(23): 4538-4549.

19. Mahato, S., Mehta, A. and Roy, S. (2013) Studies on antibacterial effects of bark, seed and callus extracts of Holarrhena antidysenterica wall. Bioscan., 8(2): 717-721. 